Lentera Pustaka: Jurnal Kajian Ilmu Perpustakaan, Informasi dan Kearsipan, 4 (2): 101-107, 2018 Copyright (O2018, ISSN: 2302-4666 print/ 2540-9638 online

Available Online at: http://ejournal.undip.ac.id/index.php/lpustaka

\title{
Exploring Case Study Method for Library and Information Science Research
}

\author{
Heriyanto $^{1 *}$ \\ ${ }^{1}$ Jurusan Ilmu Perpustakaan, Fakultas Ilmu Budaya, Universitas Diponegoro, \\ Jl. Prof. Soedarto, SH, Kampus Undip Tembalang, Semarang, Indonesia. \\ *) Korespondensi: heriyanto@live.undip.ac.id
}

\begin{abstract}
This article exploring a case study method for library and information science research aims to investigate the implementation of case study methods for Library and Information Science research. It seeks to understand how the method has been used to study the library and information phenomenon. Hence some Library and Information research that applied case study are described and analyzed. The findings show that the case study is appropriate to use for Library and Information Science research as it enables the researcher to explore the dynamics of phenomena within library settings.
\end{abstract}

Keywords: Library and Information Science; case studies; research method; libray and information science research

\begin{abstract}
Abstrak
Artikel ini berjudul Exploring Case study method for Library and Information Science Research bertujuan mengeksplorasi penggunaan metode case study pada penelitian-penelitian Ilmu Perpustakaan dan Informasi. Beragamnya metode penelitian yang digunakan dalam mengkaji fenomena-fenomena yang masuk dalam lingkup Ilmu Perpustakaan dan Informasi serta keunikan yang ada pada masing-masing metode tersebut menyampaikan pesan bahwa kajian-kajian didalam fenomena Ilmu Perpustakaan bisa dilakukan dengan pendekatan yang berbeda. Penelitian ini memilih beberapa study yang dilakukan dengan metode case study dan ditinjau beberapa hal termasuk tujuan penelitian, rumusan masalah, desain penelitian, dan hasil yang diperoleh. Hasil yang diperoleh menunjukkan bahwa case study bisa menjadi pilihan untuk penelitian dibidang Ilmu Perpustakaan dan Informasi untuk mengkaji secara mendalam dinamika didalam dunia perpustakaan dan informasi.
\end{abstract}

Kata kunci: ilmu perpustakaan dan informasi; study kasus; metode penelitian; penelitian ilmu perpustakaan dan informasi

\section{Background}

Case studies continue to be used extensively in social science research, including the traditional discipline such as psychology, sociology, history, and economics (Yin, 2003), but also in a practice-oriented field such as urban planning, management science, education, and library and information science. More to that, the method is a frequent mode of thesis and dissertation research in all of these disciplines and fields (Yin, 2003). There are some reasons researchers employing a case study method in conducting research, for instance, it provides a systematic and scientific way of examining events, collect data, analyze information, and prepare a report. As a result of this, the researcher may gain an understanding of why the phenomenon happened as it did, and what might become important to look at more extensively in future research.

Previously case study method was used in the field of clinical psychology to examine the patient's previous history about the person's mental health status. It is useful to know about the patient's physical 
and mental health and to make an accurate diagnosis. Therefore, the researchers have adequate knowledge about the patient's past and present health-related and environmental problems and issues. This method can be appropriate as it based on reality. Observation, interviews, psychological tests and inventories have been used for collecting relevant data about the case or cases. However, subjective bias is a constant issue to objective data gathering and analysis techniques. Therefore, the researcher must be thoroughly familiar with the skills which are associated with the conduct of case-studies.

Researchers describe how case studies can be used to examine complex phenomena in the natural setting to increase their understanding of the phenomena (Hamel, 1993; Yin, 2003). Case studies in research mean that the holistic nature of the phenomenon can be addressed. Furthermore, when describing the steps undertaken while using a case study approach, this method of research allows the researcher to take a complex and broad topic or phenomenon, and narrow it down into a manageable research question (Sandelowski, 1996). By collecting qualitative or quantitative datasets about the phenomenon, the researcher gains a more in-depth insight into the phenomenon that would be obtained using only one type of data (Sandelowski, 1996).

Case study research mostly refers to the use of a descriptive research approach to obtain an in-depth analysis of a person and group being studied. The various techniques were applied to the subject such as personal interviews, observation, and archival records. Generally, they are a single-case design, but few of them are a multiple-case design. One thing that is known by researchers who have used this research approach is it should provide valid and reliable results for the development of future research.

Yin (2003) stated that since the period of 1980 to 2008 the frequency for case study research shows an upward trend in contrast to the other two terms, survey research and experiment research. It can be seen that case study research may be having an increasingly notable place among researchers. However, few researches have investigated how case study research has been employed for the Library and Information Science field. Even though the case study has been used in library science research, there isn't a single study looking at how it has been applied in the Library and Information Science research. Therefore, this article aims to explore some library science research that was conducted by implementing a case study approach. But, as the number of library science research is many this article does not attempt to describe a whole library science research. Instead, it takes a few case studies that are considered to have a strong influence on the development of library science research. Most of the articles described here were obtained from the QUT Library catalog. However, the researcher was also used Google Scholar on searching any articles. Three articles selected here were found through the QUT Library catalog and one article found through Google Scholar. 


\section{Case study overview}

As a research strategy, the case study is used in many situations in order to contribute to the body of knowledge of most of context in real world of individual, group, social, political, and related phenomena (Yin, 2003). It is a method for understanding 'how' and 'why' question that will lead researchers to explore a contemporary event that is occurring (Yin, 2009), The 'how' question encourage researchers to investigate the phenomenon in order to understand what is happening and how does it happen (Yin, 2009). Case studies are conducted for a variety of purposes, such as a study of open access and its usage for enhancement of research distribution (Walker, 2009).

A case study is an empirical enquiry that explores a contemporary phenomenon within its reallife context (Yin, 2003). This research approach can be useful when the research wanted to cover contextual condition, means believing that the context might be relevant to the phenomenon being studied. The case study inquiry is also deal with distinctive situation in which commonly many variable of interest included, hence it relies on multiple sources of evidence for example a person and a document and any other historical artefacts. Therefore by employing this approach may benefits from prior development of theoretical prepositions to guide data collection and data analysis (Yin, 2003).

There are four types of case studies that are commonly known in the literatures which are illustrative case studies, exploratory case studies, cumulative case studies, and critical instance case studies. Illustrative case studies are basically descriptive studies. They utilise one or two events to show what a situation is like. It serves primarily to uncover the unfamiliar become familiar and to provide readers a lay language about the topic that was being explored. Exploratory case studies are mostly being used to identify questions and select types of measurement before the investigation begin. While cumulative case studies serve to complete information from some places collected at different times. It is hope that the collection of past studies will allow for generalisation of events without putting additional cost or time on repetitive studies. Finally, critical instance case studies intended to examine one or more sites for the purpose of assessing a situation. This method can be useful for answering cause and effect questions (Yin, 2003).

Case study mostly chosen as it provides the flexibility as a research method and depth of investigation to explore the complexities of a phenomenon being studied. There will be an opportunity, through case study, to explore, interpret and report the lived experiences of participants and to offer insights into their experiences on a specific context. More over, by implementing case study method, there is flexibility also in the mode of reporting. The researcher interprets the case and, while ensuring authenticity is maintained, can decide on how to go about representing the voices of the participants (Simons, 2009). Therefore the significant benefits in utilizing a case study approach for most of the studies described in this article, by evaluating and communicating insight into participants experiences on their real-life occurring events. 


\section{Data analysis in Case studies}

When it comes to analysing the data, some researchers may ask when can I start analysing my data. Researchers who employ case study method can actually start to analyse their data throughout their data collection process. This means, the researchers involving in ongoing examination and interpretation of the data collected in order to find tentative patterns for the investigated events. It is commonly happens because case study researchers are mostly adhere to several guidelines as they simultaneously summarize and interpret information gathered when doing case study research (Hancock \& Algozinne, 2006). For instance, one guideline requires ongoing refinement of the study's fundamental research questions in light of data obtained early in the investigation.

However, another guideline may recommend constant focus on the research questions being investigated. A case study researcher can feel overwhelmed by the large amount of information normally obtained from interviews, observations, and documents. A way to control the resulting sense of helplessness is to constantly remind oneself of the fundamental research questions being explored in the study. In other words, each new piece of information should be examined in light of the fundamental question (Hancock \& Algozinne, 2006). A third guideline involves interpretation of only data that the researchers see potentially meaningful to the research. Some researchers believe that focusing on irrelevant information can be counterproductive (Hancock \& Algozinne, 2006).

\section{Case study research in Library and Information Science studies}

Case study has been used in library and information science research (Radford \& Kern, 2006; Darke, Shanks \& Broadbent, 1998). The case study is appropriate to use for LIS research as it enables the researcher to explore the dynamics of phenomena within library settings (Eisenhardt, 1989). Case study is used in library and information science research in order to enhance the service provided by the library as well as to understand how information is best managed and delivered (Grover \& Greer, 1991). There have been four recent studies that have used case study method which are applicable to the proposed research. The most recent was conducted by Westell (2006) who aims to propose indicators for measuring the success of institutional repositories that are participating in the Canadian Association of Research Libraries (CARL) Institutional Repository Project. Repositories examined in this study included Queen's University, University of Calgary, University of Manitoba, University of New Brunswick, University of Saskatchewan, University of Toronto, University of Waterloo, and University of Winnipeg.

Using case study approach, Westell examined the repositories through a review of their web presence and their integration with university library and research pages. The proposed indicators (e.g mandate, integration with planning, funding model, relationship with digitization centres, interoperability, measurement, promotion and preservation strategy) were used to test on the repositories. Using the 
observational results, Westell compared all the Institutional Repositories to the proposed indicators. The study found that integration into the larger academy, through a general mandate, prominence in planning documents, institutional sustainability funding, promotion, visibility of content and web pages, is critical to the success of an institutional repository.

Armbruster (2010) conducted case study by examining the implementation of open access in 9 countries, including QUT which is seen as a pioneer in implementing a repository mandate to their researchers. The study was looking at the policy that has been designed and implemented and analyzing the open access content, e.g. the types of research papers published in the open access. This study is based on number of cases that is reconstructed individually on the basis of public documents and supported by interviews with experts responsible for the open access implementation. This open access case study implemented sampling, interviews, and validation technique in collecting and analyzing data. Cases was selected from some universities that was considered to be appropriate to represent the cases, for instance the mandate, the university policy for implementing open access and a mandate for researchers to archive their scholarly works.

Semi-structured interviews were also conducted with some experts who is in charge of implementing open access policies to exploring. The interview was purposed to get the lived-experience of the experts on managing the open access policy.

The data analysis was started by analyzing the qualitative data, which was collected from the interviews. This stage was consisting of summation and reduction to the essential elements, then delineation of the major categories of meaning and interpretation, and explication of context and any unclear issues; and finally, structuration of text (Armbruster, 2010).

The next step was what Armbruster call it communicative validation. This step was done by returning the draft of analysis to the participants who were interviewed for more discussion, comments, and approval. Following that, the analysis was also discussed with outside experts in the field.

Interestingly, this study do not come with generalization for the objects being investigated. Instead, it put an emphasis on variety and on defining a methodological standard. As described earlier, each case is reconstructed individually on the basis of public documents and background information, and supported by interviews with experts responsible for open access implementation.

In term of content, Koskinen et al. (2010) also conducted case study research looking out how many research articles archived by the University of Helsinki can be reached by the readers as open access text. The study has selected peer reviewed articles that was published in 2007 to 2008. The articles were downloaded from the University of Helsinki publication database named JULKI as a sample. This is the 
university database contains information about research project publications and other material published by university staff members. At the time the articles downloaded, 7771 articles were retrieved at that period and 407 articles were selected using random sample technique.

In term of the article's accessibility, five Internet search tools were used to determine the open web accessibility of the selected articles as research samples. It included two search engines, two open access metadata harvesters, and the University of Helsinki institutional repository named Helda. All of these search tools were used to find the articles and the searches were conducted both within the university network as well as from outside of the network. Although Google and Google scholar perform well in finding the articles, the research found that the open access metadata harvester cannot be ignored. Since there are articles that the two famous search engines cannot reach (Koskinen et al.,2010), therefore the research suggest to use open access directories to obtain more comprehensive search result.

The data analysis processes in Koskinen et al's study was involving the research articles that were downloaded from the university database and analyzed based on their findability both through some channels, which are five different search engines (that includes Google and Google Scholar), and the university Helsinki repository. All of the search activity were trying to answer the main question: did the full text of the article open? The study found that openly available versions of research articles can be found from publisher sites, digital repositories, web pages of research groups, and personal web pages.

\section{Conclusion}

In summary, the applications of a case study as a research method were used to address questions like "how does something happen?" or why does something happen?". It is an explanatory question that relates to a specific context that happens in a particular place. Case study method was used to evaluate system applied for open access and the open access accessibility. Its application to the four research described in this article may provide evidences that the dynamic of Library and Information Science research can be conducted through many methods, and that include case study approach.

It is expected that the findings from this study could contribute to the discussion of the research method for the Library and Information Science field, especially for the application of case study method. Secondly, the findings provide insights about any aspects from the Library and Information Science that can be explored using case study methods but also raising further opportunity to be investigated using different research methods.

\section{References}


Armbruster, C. (2010). Implementing Open Access: Policy case studies. Retrieved from Social Science Research Network http://ssrn.com/abstract=1685855

Darke, P., Shanks, G., \& Broadbent, M. (1998). Successfully completing case study research: Combining rigour, relevance and pragmatism. Information Systems Journal, 8(4), 273-289.

Eisenhardt, K. M. (1989). Building theories from case study research. Academy of Management Review, 14(4), 532-550

Grover, R. \& Greer, R.C. (1991). The Cross-disciplinary Imperative of LIS Research. Library and Information Science Research: Perspective and Strategies for Improvement, p.101-113.

Hamel, J. (1993). Case study methods. Newbury Park: Sage

Hancock, D.R., \& Algozinne, B. (2006). Doing case study research: a practical guide for beginning researchers. New York, Columbia University

Koskinen, K., Lappalainen, A., Liimatainen, T., Niskala, A., Salminen, P. J., \& Nevalainen, E. (2010). The Current State of Open Access to Research Articles from the University of Helsinki. ScieCom Inf,, 6(4). Retrieved from http://www.sciecom.org/ojs/index.php/sciecominfo/article/view/4761

Radford, M. L., \& Kern, M.K. (2006). A Multiple-case Study Investigation of the Discontinuation of Nice Chat Reference Services. Library \& Information Science Research, 28, p.521-547, doi:10.1016/j.lisr.2006.10.001

Sandelowski, M. (1996). One is the liveliest number: the case orientation of qualitative research. Res Nurs Health, 19, 525-9.doi:10.1002/(SICI)1098-240X(199612)19:6<525::AID-NUR8>3.0.CO;2-Q

Westell, M. (2006). Institutional Repositories: Proposed Indicators of Success. Library Hi Tech, 24(2), p.211-226. Retrieved from http://dx.doi.org/10.1108/07378830610669583

Yin, R.K. (2003). Case study research, $3^{\text {rd }}$ ed. Thousand Oaks, Sage Publications 